\title{
Antibiotic use Profiles and Microbial Patterns in the Surgery Department of Bangil Regional General Hospital, Pasuruan
}

\author{
Fauna Herawati ${ }^{1 *}$, Beatrix Eyleen Giovanny ${ }^{1}$, Rika Yulia1and Abdul Kadir Jaelani ${ }^{2}$ \\ ${ }^{1}$ Faculty of Pharmacy, University of Surabaya, Surabaya \\ ${ }^{2}$ Regional General Hospital Bangil, Jl. Raya Raci - Bangil,Indonesia
}

Submission: September 04, 2018; Published: October 25, 2018

*Corresponding author: FaunaHerawati, Faculty of Pharmacy, University of Surabaya, Jalan Raya Kalirungkut, FF Building, $5^{\text {th }}$ Floor, Surabaya 60293, Indonesia, Tel: 6231 2981212: E-mail: fauna@staff.ubaya.ac.id

\begin{abstract}
This study aimed to determine the profile of the use of antibiotics in units of DDD / 100 patient-days, types of bacteria as well as the sensitivity of bacteria in the Surgery Department of Bangil Regional General Hospital, Pasuruan during the period from January to June 2016. The study was conducted using a descriptive, cross-sectional study design and data collection was done retrospectively. Nineteen percent patients in the surgical ward was given antibiotic. The results showed that the 3 most-used antibiotics are ciprofloxacin (11.8 DDD / 100 patient-days), ceftazidime (6.7 DDD / 100 patient-days), and cefixime (4.3 DDD / 100 patient-days). Ciprofloxacin became the most widely used antibiotics with DU of $26 \%$ from the total antibiotic. Within six months, there are four bacteria identified from the culture test result, i.e.: Staphylococcus aureus, Klebsiella pneumoniae, Stenotrophomonas maltophilia and Acinetobacter sp. Only vancomycin is an antibiotic which has $100 \%$ sensitivity to S. aureus. The DDD / 100 patient-days for $19 \%$ patients is 45.83 , this result shows that the trend of using antibiotic is more than one DDD antibiotic per day.
\end{abstract}

Keywords: Antibiotic; ATC/DDD; DU 90\%; Sensitivity of bacteria; Surgical department

Key message: Antibiotic stewardship programme is urgently needed due to a high antibiotic use in the hospital

\section{Introduction}

Infectious diseases are one of the causes of high morbidity and mortality. Data obtained from the World Health Organization (WHO) showed that infectious diseases have caused 1.4 million deaths per days in the world and developing countries, including Indonesia. A study conducted at several hospitals in Indonesia in 2004 showed that $9.8 \%$ of hospitalized patients suffered from nosocomial infections. According to the Ministry of Health, Republic Indonesia, in 2011, the incidence of surgical wound infections in public hospitals amounted to $55.1 \%$.

Bacterial infections could be treated with antibiotics. However, the success of antibiotics in curing infections creates a new problem, which is the growing population of bacteria being resistant to antibiotics. Inappropriate use of antibiotics will result in bacteria or microbes becoming resistant to the antibiotic, thus causing the antibiotics to lose their functions[1-4]. Based on an assessment carried out in Dr. Soetomo General Hospital (Surabaya) and Dr. Kariadi General Hospital Medical Center (Semarang) regarding wise use of antibiotics, it was proven that $30 \%$ to $80 \%$ of the antibiotics used were not based on indications[5].
Controlling the use of antibiotics is considered necessary to reduce the incidence of antibiotic resistance. One way of doing so is through the implementation of an Antibiotic Stewardship Program, which is an institutional or healthcare system approach to promote and monitor the use of antibiotics appropriately to maintain its effectiveness. The Ministry of Health in Indonesia has established an Antimicrobial Resistance Control Program (ARCP) team to support and oversee the running of Antibiotic Stewardship Program, which is recommended by the World Health Organization (WHO) and the Centers for Disease Control and Prevention (CDC). The Health Ministerial Regulation of 2015 states that every hospital in Indonesia must implement an Antimicrobial Resistance Control Program optimally[6-8].

\section{Materials and Methods}

This research is a retrospective, descriptive, observational cross-sectional study. The research material was data on antibiotic usage in the Surgery Department of Regional General Hospital Bangil during January - June 2016 period obtained from the Pharmacy Installation of Regional General Hospital Bangil, which was then calculated and expressed in DDD units (defined 
daily dose) per 100 patient days, as well as calculated using Drug Utilization 90\% (DU 90\%) method to discover the most widely used antibiotics within 6 months. In addition, data on bacterial culture obtained from the microbiology laboratory of Regional General Hospital Bangil were also used to find out the types of bacteria and the percentage of bacterial sensitivity in the Surgery Department of Regional General Hospital Bangil during the period of January - June 2016. The formula to calculate DDD per 100 patient-days is modified from DDD/1000 population/day as follows:[8-10].

DDD $/ 1000$ population/day $=\frac{\text { Amount used in } 1 \text { year }(\mathrm{mg}) * 1000}{\text { DDD }(\mathrm{mg}) \times \text { population } \mathrm{x} 365(\text { days })}$ DD $(\mathrm{mg}) \mathrm{x}$ population $\mathrm{x} 365$ (days) $\quad \cdots . . . . . . .$. Equation 1

Several adjustments to the formula are i. the specific period of a month, ii. patient-day derived from the total length of stays of

\section{Results}

Table 1: Types antibiotics based on its drug utilization (DU)O, oral; P, parenteral.

\begin{tabular}{|c|c|c|c|c|c|}
\hline NO & ATCs & Generic Name & DDD/100 Patient-Days & DU & DsU Cumulative \\
\hline 1 & J01MA02 & Ciprofloxacin (O/P) & 11.78 & $25.70 \%$ & $25.70 \%$ \\
\hline 2 & J01DD02 & Ceftazidime (P) & 6.66 & $14.53 \%$ & $40.23 \%$ \\
\hline 3 & J01DD08 & Cefixime (0) & 4.27 & $9.32 \%$ & $49.56 \%$ \\
\hline 4 & J01XD01 & Metronidazole (P) & 3.93 & $8.57 \%$ & $58.12 \%$ \\
\hline 5 & J01GB03 & Gentamicin $(\mathrm{P})$ & 3.32 & $7.25 \%$ & $65.38 \%$ \\
\hline 6 & J01DB05 & Cefadroxil $(0)$ & 3.00 & $6.55 \%$ & $71.92 \%$ \\
\hline 7 & J01DD04 & Ceftriaxone (P) & 2.19 & $4.79 \%$ & $76.71 \%$ \\
\hline 8 & J01CA04 & Amoxicillin $(\mathrm{O} / \mathrm{P})$ & 2.08 & $4.53 \%$ & $81.24 \%$ \\
\hline 9 & J01GB06 & Amikacin (P) & 1.83 & $4.00 \%$ & $85.24 \%$ \\
\hline 10 & J01DH02 & Meropenem (P) & 1.76 & $3.83 \%$ & $89.07 \%$ \\
\hline 11 & P01AB01 & Metronidazole (0) & 1.67 & $3.64 \%$ & $92.71 \%$ \\
\hline 12 & J01CA01 & Ampicilin (P) & 1.09 & $2.38 \%$ & $95.10 \%$ \\
\hline 13 & J01DC02 & Cefuroxime (P) & 0.92 & $2.00 \%$ & $97.10 \%$ \\
\hline 14 & J01CR01 & Ampicillin/Sulbactam (P) & 0.40 & $0.87 \%$ & $97.97 \%$ \\
\hline 15 & J01MA12 & Levofloxacin (P) & 0.30 & $0.66 \%$ & $98.63 \%$ \\
\hline 16 & J01DD01 & Cefotaxime $(\mathrm{P})$ & 0.25 & $0.54 \%$ & $99.17 \%$ \\
\hline 17 & J01FA10 & Azithromycin $(0)$ & 0.19 & $0.42 \%$ & $99.59 \%$ \\
\hline 18 & J01CR02 & Amoxicilin/Clavulanic Acid (0) & 0.12 & $0.26 \%$ & $99.84 \%$ \\
\hline 19 & J01FF01 & Clindamycin (0) & 0.06 & $0.13 \%$ & $99.98 \%$ \\
\hline \multirow[t]{2}{*}{20} & J01FA01 & Erythromycin (0) & 0.01 & $0.02 \%$ & $100.00 \%$ \\
\hline & \multicolumn{2}{|r|}{ TOTAL } & 45.83 & $100.00 \%$ & \\
\hline
\end{tabular}

From a total of 3016 patients in the surgical wards of Regional General Hospital Bangil, 572 patients received antibiotic therapy. In this research, 20 types of antibiotics consisting of 9 oral and 13 parenteral preparations were used. The total number of DDD / 100 patient-days in the surgical wards in January was 45.83 , the detailed data could be seen in (Table 1).

According to these data, the 3 (three) most commonly used ciprofloxacin (11.78 DDD / 100 patient-days), ceftazidime (6.66 antibiotics in the surgical wards during January - June 2016 were the patient. The DDD is the assumed average maintenance dose per day for a drug used for its main indication in adults.

\section{Population and Sample Determination}

The defined daily dose (DDD) per 100 patient-days and DU90\% data were derived and calculated from pharmacy databases; whereas a bacterial culture test was from any adult patient (aged $\geq 14$ years) specimen in the surgical ward of Regional General Hospital Bangil in the period of January-June 2017.

\section{Data Analysis}

The data analysis in this study is a descriptive analysis. The calculation results of antibiotics use and percentage of bacterial sensitivity to antibiotics are presented in the form of graphs and tables.
DDD / 100 patient-days), and cefixime (4.27 DDD / 100 patientdays). The $90 \%$ DU antibiotics during the period from January to June 2016 there were ciprofloxacin, ceftazidime, cefixime, metronidazole, gentamicin, cefadroxil, ceftriaxone, amoxicillin, amikacin, meropenem. Based on data obtained from the microbiology laboratory, 35 isolates were found, and 25 antibiotics were tested on sensitivity to 14 bacteria, as shown in (Table 2). These bacteria are Gram-negative bacteria, such as Acinetobacter Sp.(7), Escherichia coli(2), Enterobacteraerogenes(1), Enterobacter agglomerous(2), Enterobactercloacae(1), Klebsiella 
ozaenae(1), Klebsiellapneumoniae (3), Pragia fontium(1), Shigella positive bacteria, such as Staphylococcus aureus(9), Staphylococcus dysenteriae(1), Stenotrophomonas maltophilia(4) and Gram- simulans(1), Streptococcus mitis (1), Streptococcus pyogenes(1).

Table 2: Total Isolates Bacterial in the Surgical Wards during January - June 2016.

\begin{tabular}{|c|c|c|c|c|c|c|c|c|}
\hline Gram of bacteria & Type of bacteria & Jan & Feb & March & April & May & June & Total \\
\hline \multirow{11}{*}{ Gram Negative } & Acinetobacter Sp. & 1 & 0 & 1 & 2 & 2 & 1 & 7 \\
\hline & Stenotrophomonas maltophilia & 0 & 1 & 2 & 0 & 1 & 0 & 4 \\
\hline & Klebsiella pneumoniae & 0 & 0 & 0 & 1 & 2 & 0 & 3 \\
\hline & Escherichia coli & 0 & 1 & 1 & 0 & 0 & 0 & 2 \\
\hline & Enterobacter agglomerou & 0 & 0 & 1 & 0 & 0 & 1 & 2 \\
\hline & Enterobacter aerogenes & 0 & 0 & 1 & 0 & 0 & 0 & 1 \\
\hline & Enterobacter cloacae & 0 & 0 & 0 & 0 & 0 & 1 & 1 \\
\hline & Klebsiella ozaenae & 0 & 1 & 0 & 0 & 0 & 0 & 1 \\
\hline & Pragia fontium & 0 & 1 & 0 & 0 & 0 & 0 & 1 \\
\hline & Shigella dysenterid & 0 & 0 & 1 & 0 & 0 & 0 & 1 \\
\hline & Total Gram-Negative Bacteria & 1 & 4 & 7 & 3 & 5 & 3 & 23 \\
\hline \multirow{6}{*}{ Gram Positive } & Staphylococcus aureus & 1 & 2 & 2 & 1 & 1 & 2 & 9 \\
\hline & Staphylococcus simulans & 0 & 0 & 0 & 0 & 1 & 0 & 1 \\
\hline & Streptococcus mitis & 0 & 0 & 0 & 0 & 1 & 0 & 1 \\
\hline & Streptococcus pyogenes & 0 & 0 & 0 & 1 & 0 & 0 & 1 \\
\hline & Total Gram-Positive Bacteria & 1 & 2 & 2 & 2 & 3 & 2 & 12 \\
\hline & Total & 2 & 6 & 9 & 5 & 8 & 3 & 35 \\
\hline
\end{tabular}

Table 3: Gram Negative and Positive Bacterial Isolates Resistant to Antibiotics. n: number of resistant isolates; N: number of total isolates.

\begin{tabular}{|c|c|c|c|c|c|c|c|c|c|}
\hline \multirow{3}{*}{ KODE ATC } & \multirow{3}{*}{ Nama Antibiotik } & \multicolumn{6}{|c|}{ Gram Negatif } & \multirow{2}{*}{\multicolumn{2}{|c|}{$\begin{array}{c}\text { Gram Positif } \\
\begin{array}{c}\text { Staphylococcus aureus } \\
(\mathrm{N}=9)\end{array}\end{array}$}} \\
\hline & & \multicolumn{2}{|c|}{ Acinetobacter $S p(\mathrm{~N}=7)$} & \multicolumn{2}{|c|}{$\begin{array}{l}\text { Klebsiella pneumoniae } \\
(\mathrm{N}=3)\end{array}$} & \multicolumn{2}{|c|}{$\begin{array}{l}\text { Stenotrophomonas } \\
\text { maltophilia }(\mathrm{N}=4)\end{array}$} & & \\
\hline & & $\mathrm{n}$ & $\%$ & $\mathrm{n}$ & $\%$ & $\mathrm{n}$ & $\%$ & $\mathrm{n}$ & $\%$ \\
\hline J01AA02 & Doxycycline & - & - & - & - & - & - & 0 & 0 \\
\hline J01AA07 & Tetracycline & - & - & - & - & - & - & $2 / 9$ & $22 \%$ \\
\hline J01AA08 & Minocycline & $5 / 7$ & $71 \%$ & $2 / 3$ & $67 \%$ & $2 / 4$ & $50 \%$ & $3 / 9$ & $33 \%$ \\
\hline J01BA01 & Chloramphenicol & - & - & - & - & - & - & $5 / 9$ & $56 \%$ \\
\hline J01C & Penicillin & - & - & - & - & - & - & $9 / 9$ & $100 \%$ \\
\hline J01CA01 & Ampicillin & $5 / 7$ & $71 \%$ & $3 / 3$ & $100 \%$ & $4 / 4$ & $100 \%$ & - & - \\
\hline J01CA12 & Piperacillin & $5 / 7$ & $71 \%$ & $3 / 3$ & $100 \%$ & $2 / 4$ & $50 \%$ & - & - \\
\hline J01CF04 & Oxacillin & - & - & - & - & - & - & $3 / 9$ & $33 \%$ \\
\hline J01CR01 & $\begin{array}{l}\text { Ampicillin/ } \\
\text { Sulbactam }\end{array}$ & $4 / 7$ & $57 \%$ & $3 / 3$ & $100 \%$ & $4 / 4$ & $100 \%$ & - & - \\
\hline J01CR05 & $\begin{array}{l}\text { Piperacillin/ } \\
\text { Tazobactam }\end{array}$ & $5 / 7$ & $71 \%$ & $1 / 3$ & $33 \%$ & $2 / 4$ & $50 \%$ & - & - \\
\hline J01DB04 & Cefazolin & $6 / 7$ & $86 \%$ & $3 / 3$ & $100 \%$ & $4 / 4$ & $100 \%$ & - & - \\
\hline J01DC01 & Cefoxitin & $6 / 7$ & $86 \%$ & $2 / 3$ & $67 \%$ & $4 / 4$ & $100 \%$ & $1 / 9$ & $11 \%$ \\
\hline J01DC02 & Cefuroxime & $5 / 7$ & $71 \%$ & $3 / 3$ & $100 \%$ & $4 / 4$ & $100 \%$ & - & - \\
\hline J01DD02 & Ceftazidime & $1 / 7$ & $14 \%$ & $3 / 3$ & $100 \%$ & $1 / 4$ & $25 \%$ & - & - \\
\hline J01DD04 & Ceftriaxone & 0 & 0 & $3 / 3$ & $100 \%$ & $4 / 4$ & $100 \%$ & - & - \\
\hline J01DE01 & Cefepime & $5 / 7$ & $71 \%$ & $2 / 3$ & $67 \%$ & $1 / 4$ & $25 \%$ & - & - \\
\hline J01DF01 & Aztreonam & $3 / 7$ & $43 \%$ & $2 / 3$ & $67 \%$ & $2 / 4$ & $50 \%$ & - & - \\
\hline J01DH02 & Meropenem & 0 & 0 & $2 / 3$ & $67 \%$ & $3 / 4$ & $75 \%$ & - & - \\
\hline J01EE01 & Cotrimoxazole & $5 / 7$ & $71 \%$ & $3 / 3$ & $100 \%$ & $4 / 4$ & $100 \%$ & $1 / 9$ & $11 \%$ \\
\hline
\end{tabular}


Global Journal of Pharmacy \& Pharmaceutical Sciences

\begin{tabular}{|c|c|c|c|c|c|c|c|c|c|}
\hline J01FA01 & Erythromysin & - & - & - & - & - & - & $2 / 9$ & $22 \%$ \\
\hline J01FA10 & Azithromycin & - & - & - & - & - & - & $2 / 9$ & $22 \%$ \\
\hline J01FF01 & Clindamycin & - & - & - & - & - & - & $2 / 9$ & $22 \%$ \\
\hline J01GB01 & Tobramicin & $5 / 7$ & $71 \%$ & $3 / 3$ & $100 \%$ & $3 / 4$ & $75 \%$ & 0 & 0 \\
\hline J01GB03 & Gentamicin & $5 / 7$ & $71 \%$ & $2 / 3$ & $67 \%$ & $3 / 4$ & $75 \%$ & $6 / 9$ & $67 \%$ \\
\hline J01GB06 & Amikacin & $5 / 7$ & $71 \%$ & $2 / 3$ & $67 \%$ & $3 / 4$ & $75 \%$ & 0 & 0 \\
\hline J01MA01 & Ofloxacin & - & - & - & - & - & - & $3 / 9$ & $33 \%$ \\
\hline J01MA02 & Ciprofloxacin & $5 / 7$ & $71 \%$ & $2 / 3$ & $67 \%$ & $3 / 4$ & $75 \%$ & $3 / 9$ & $33 \%$ \\
\hline J01MA06 & Norfloxacin & $5 / 7$ & $71 \%$ & $2 / 3$ & $67 \%$ & $1 / 4$ & $25 \%$ & $3 / 9$ & $33 \%$ \\
\hline J01MA07 & Lomefloxacin & - & - & - & - & $1 / 4$ & $25 \%$ & $1 / 9$ & $11 \%$ \\
\hline J01MA12 & Levofloxacin & $7 / 7$ & $100 \%$ & $2 / 3$ & $67 \%$ & $3 / 4$ & $75 \%$ & $1 / 9$ & $11 \%$ \\
\hline J01MA14 & Moxifloxacin & - & - & - & - & - & - & $3 / 9$ & $33 \%$ \\
\hline J01MA16 & Gatifloxacin & - & - & - & - & - & - & $1 / 9$ & $11 \%$ \\
\hline J01XA01 & Vancomycin & - & - & - & - & - & - & 0 & 0 \\
\hline J01XX08 & Linezolid & - & - & - & - & - & - & $1 / 9$ & $11 \%$ \\
\hline
\end{tabular}

Having tested the four isolates, it was found that Klebsiella pneumoniae bacteria were the most resistant to antibiotics. (Table 3) shows the percentage of antibiotic resistance in Klebsiella pneumonia. It could be seen that resistance to most of the antibiotics tested was found, such as to gentamicin, ciprofloxacin, ceftriaxone, ceftazidime, and meropenem. Those antibiotics were considered as the top 10 most-used antibiotics in the Surgical Wards of Bangil Regional General Hospital during the period of January-June 2016.

\section{Discussion}

The number of DDD / 100 patient days was 45.83. This number is like the number of antibiotics used in the surgical wards of Dr. Karjadi Hospital in Semarang in 2008, which was 51.8 DDD / 100 patient-days[5,11-13]. The number of antibiotics used was a combined data from all patients in the surgical wards who used antibiotics without looking at the diagnosis, thus the value of DDD cannot described its appropriateness to every indication. It is necessary to conduct further research that considers the patient diagnosis during antibiotic therapy and other factors influencing the use of antibiotics.

In the calculation result regarding the number of DDD / 100 patient days, the major parenteral antibiotics used during the months of January to June 2016 were also reported, i.e. ceftazidime (6.66 DDD / 100 patient days). The increase in the use of ceftazidime may be due to a shortage of ceftriaxone injection in the Pharmacy Department of Regional General Hospital Bangil in the early 2016, which was most widely used in the surgical wards of Regional General Hospital Bangil. A research conducted at Dr. Kariadi Hospital in Semarang also suggested that the most widely used antibiotics was ceftriaxone amounting to 36.9 DDD / 100 patient-days.5 The use of ceftazidime as a substitute for ceftriaxone is appropriate as both ceftazidime and ceftriaxone are in the same class of antibiotics, which are the third-generation cephalosporins. The high level of ciprofloxacin use in the surgical wards could be caused by several factors, such as the administration of oral dosage after patients were discharged from the hospital and the diagnosis during hospital stays in the Surgical Wards of Regional General Hospital Bangil.

The use of ceftazidime in the form of injections was also relatively high because, at the beginning of 2016, the Pharmacy Department of Regional General Hospital Bangil had a shortage of ceftriaxone injection, which was most widely used in the surgical ward of Regional General Hospital Bangil. The reasons for ceftazidime's highly use is as a substitution for ceftriaxone during the period of January-June 2016. These factors could be used as a reference for further research regarding the use of antibiotics in surgical wards. From the data on DDD / 100 patient days of each antibiotic, the $90 \%$ DU segment was then calculated to identify the most commonly used antibiotics in the surgical wards. Antibiotics in the $90 \%$ DU segment in order from largest to smallest were ciprofloxacin (26\%), ceftazidime (15\%), cefixime (9\%), metronidazole $(9 \%)$, gentamicin $(7 \%)$, cefadroxil $(7 \%)$, ceftriaxone (5\%), amoxicillin (5\%), amikacin (4\%), meropenem (4\%). Ciprofloxacin antibiotics were the most widely used antibiotics with DU of $26 \%$. The antibiotics in the $90 \%$ Cumulative list were the types of antibiotics recommended in the National Formulary, published in 2016.

The use of antibiotics as therapy in patient care greatly affects the growth of bacteria, in which they could become resistant to antibiotics that do not correspond to the existing resistance patterns. Therefore, the researchers collected data regarding the results of bacterial culture to find out the types of bacteria that grew and antibiotic sensitivity in the surgical wards of Regional General Hospital Bangil during January to June 2016. The four bacteria could grow and cause surgical site infections (SSI) in the surgical wards[11]. In the surgical wards of Bangil Hospital, the culture test is not always performed on SSI patients, but also on patients diagnosed open fractures. This is like the results of a study carried out at a hospital in Yogyakarta during August 
2013-August 2015, as the types of bacteria that grew were the same as in the surgical wards of Regional General Hospital Bangil, such as Staphylococcus aureus(12), AcinetobacterSp. (3), Stenotrophomonas maltophilia(1), and Klebsiella pneumoniae(1) [14].

The four bacteria were then calculated on the percentage of sensitivity and resistance to antibiotics. The result showed that Klebsiella pneumoniae bacteria were resistant to most antibiotics. All Staphylococcus aureus bacteria sensitive to vancomycin (100\%). From these data, we cannot obtain microbial patterns because the number of isolates of each bacterium was insufficient and not all specimens gave positive isolate in the culture test. In addition, it was not possible to calculate the sensitivity percentages of several antibiotics due to the small number of isolates. These sensitivity test bacteria to antibiotics are classified into 3 (three) categories, i.e.: usually effective clinically, if the antibiotic sensitivity test result is more than $60 \%$ of all examinations; intermediate effective clinically, if the antibiotic sensitivity test result is between $30-60 \%$ of all examinations; and not effective clinically, if the antibiotic sensitivity test result is less than $30 \%$ based on Sanford Guide to Antimicrobial Therapy 40th ed, [15]. Further research is required to obtain enough isolates and results of all antibiotic susceptibility tests.

\section{Conclusion}

From a total of 3016 patients in the surgical wards of Bangil Regional General Hospital, 572 patients used antibiotics. The number of DDD / 100 patient days was obtained from data on antibiotics use in the surgical wards of Regional General Hospital Bangil. The most antibiotics use in the surgical wards was ciprofloxacin.

There were 14 bacteria growing during a cultural test carried out on 35 antibiotics, which consisted of 23 gram-positive bacterial isolates and 12 gram-negative bacterial isolates. Those bacteria were mostly gram-negative bacteria (Acinetobacter Sp., Klebsiella pneumoniae, Stenotrophomonas maltophilia) and gram-positive bacteria (Staphylococcus aureus). The most commonly used types of antibiotics resistant to Klebsiella pneumonia in the surgical wards during January-June 2016 period were gentamicin, ciprofloxacin, ceftriaxone, ceftazidime, and meropenem. Based on the research that has been conducted, the following suggestions could be given: i. Further prospective research is necessary to obtain enough cultural isolates to determine the microbial patterns in the Surgery Department of Regional General Hospital Bangil, ii. Testing bacterial culture on patients who take antibiotics after 3 days and who use prophylactic antibiotics and suffer from a surgical site infection, iii. Further research on the use of antibiotics about patient diagnosis is required, iv. Updating antibiotic therapeutic guideline related to antibiotics use based on the microbial pattern in the surgical wards.

\section{Conflict of Interest}

The authors declare no conflict of interest among parties.

\section{References}

1. ATC World Health organization (2014) Antimicrobial Resistance Global Report on Surveillance. World Health Organization, Geneva, Switzerland.

2. World Health Organization (2013) The world health report 2013: research for universal health coverage. World Health Organization, Geneva, Switzerland.

3. Centers for Disease Control and Prevention (2013) Office of Infectious Disease. Antibiotic resistance threats in the United States.

4. Ventola CL (2015) The Antibiotic Resistance Crisis - Part 1: Causes and Threats 40(4): 227-278.s

5. Hadi U, Duerink DO, Lestari ES, Nagelkerke NJ, Keuter M, et al. (2008) Audit of Antibiotic Prescribing in Two Governmental Teaching Hospitals in Indonesia. European Society of Clinical Microbiology and Infectious Disease 14(7): 698-707.

6. Doron S, Davidson LE (2011) Antimicrobial Stewardship. Mayo clinic proceedings 86(11): 1113-23.

7. Peraturan Menteri Kesehatan Republik Indonesia Nomor 8 Tahun 2015 Tentang Program Pengendalian Resistensi Antimikroba Di Rumah Sakit (2015) Jakarta: Kementerian Kesehatan Republik Indonesia.

8. Kementerian Kesehatan Republik Indonesia (2011) Pedoman Pelayanan Kefarmasian Untuk Terapi Antibiotik. Direktorat Jendral Bina Kefarmasian dan Alat Kesehatan Jakarta, Indonesia, p.35-36.

9. ATC/DDD Index 2017.

10. Introduction to drug utilization research (2003) WHO International Working Group for Drug Statistics Methodology, WHO Collaborating Centre for Drug Statistics Methodology, WHO Collaborating Centre for Drug Utilization Research and Clinical Pharmacological Services 2003.

11. Yezli S, Frederic B, Jonathan AO (2014) Surface Contamination in Operating Rooms: A Risk for Transmission of Pathogens. Surgical Infections 15(6): 694-9.

12. Laras NW, Farida H (2012) Kuantitas Penggunaan Antibiotik Di Bangsal Bedah dan Obstetri-Ginekologi RSUP Dr. Kariadi Setelah Kampanye PP-PRA. Fakultas Kedokteran Universitas Diponegoro. Jurnal Media Medika Muda 1: 1.

13. Rahayuningsih N, Yuli M (2017) Evaluasi Penggunaan Antibiotik Sefalosporin Di Ruang Perawatan Bedah Salah Satu Rumah Sakit Di Kabupaten Tasikmalaya. Jurnal Kesehatan Bakti Tunas Husada 17(1): $1-9$.

14. Wiguna DS (2016) Pola Resistensi Bakteri Terhadap Antibiotik Pada Penderita Infeksi Luka Operasi (ILO) Di Rumah Sakit X Periode Agustus 2013-Agustus 2015 [skripsi]. Fakultas Farmasi Universitas Muhammadiyah Surakarta, Indonesia.

15. Gilbert David N, Moellering RC, Eliopoulos GM (2010) The Sanford Guide Antimicobial Therapy. ( $40^{\text {th }}$ ed). p. 66-71. 
Your next submission with Juniper Publishers will reach you the below assets

- Quality Editorial service

- Swift Peer Review

- Reprints availability

- E-prints Service

- Manuscript Podcast for convenient understanding

- Global attainment for your research

- Manuscript accessibility in different formats ( Pdf, E-pub, Full Text, Audio)

- Unceasing customer service

Track the below URL for one-step submission https://juniperpublishers.com/online-submission.php 